\title{
A new species of leaffish Polycentrus Müller \& Troschel, 1849 (Percomorpha: Polycentridae) from the rio Negro, Brazil
}

\author{
Daniel Pires Coutinho' and Wolmar Benjamin Wosiacki²
}

\begin{abstract}
A new species of Polycentrus is described from the rio Negro, in Brazil. It is distinguished from P. schomburgkii by the presence of two dark postocular and one subocular band, all smaller than orbital diameter, blunt snout, isognathous mouth, reduction of the serrations on the lower edge of the lacrimal-spines ranging from zero to two tiny spines at the posterior end, intensely serrated edge of the interopercle, fully serrated posterior edge of the vertical arm of the preopercle, presence of five pungent opercular spines, subopercle broadly serrated along most of its posterior ventral edge, presence of serrations dorsally on the posterior margin of the cleithrum, fourth ray of pectoral fin reaching the vertical through the anal-fin origin, 19-21 predorsal scales, 19-20 scales on dorsal-fin base, 12-14 scales on anal-fin base, and absence of a median opercular blotch.

Uma nova espécie de Polycentrus é descrita do rio Negro, Brasil. Distingue-se de P. schomburgkii por duas bandas postoculares escuras e uma banda subocular menores do que o diâmetro do olho, focinho pontudo, boca isognata, cinco espinhos operculares pungentes, borda posterior do braço vertical do pré-opérculo totalmente serrilhada, serrilhas ausente na borda inferior do lacrimal ou duas pequenas serrilhas na margem posterior, subopercular amplamente serrilhada ao longo da borda, cleitro com serrilhas na margem posterior do processo dorsal, interopercular com borda amplamente serrilhada, quarto raio da nadadeira peitoral atingindo a vertical de origem da nadadeira anal, 19-20 escamas na base da nadadeira dorsal, 12-14 escamas na base de nadadeira anal, 19-21 escamas pré-dorsais e ausência de mancha opercular.
\end{abstract}

Key words: New Taxon, Freshwater, Neotropic, Taxonomy, Systematics.

\section{Introduction}

The leaffishes of the family Polycentridae includes two South American genera, Polycentrus Müller \& Troschel and Monocirrhus Heckel, and two African genera, Afronandus Meinken and Polycentropsis Boulenger, all of them monotypic. All species are characterized by a strongly compressed body, very large, protrusible gape and a color pattern mimicking dead leaves, used to approach prey fishes. (Liem, 1970; Britz \& Kullander, 2003).

Polycentrus currently includes only $P$. schomburgkii Müller \& Troschel type species by monotypy. The species was described first briefly (Müller \& Troschel, 1849a), and subsequently presented in more detail and with illustration (Müller \& Troschel, 1849b). The description is based on a single specimen collected by Richard Schomburgk with locality information "Guiana". The species has since been reported from many coastal drainages from the state of Amapá in Brazil, north to Trinidad and Tobago, and adjacent Venezuela (Britz \& Kullander, 2003). Three nominal species have been synonymized with $P$. schomburgkii, viz. Labrus punctatus Linnaeus (International Commission on Zoological Nomenclature, 2000), P. tricolor Gill (Britz \& Kullander, 2003) from Trinidad, and Mesonauta surinamensis Sauvage (Paepke, 1993) from Suriname.

The Expedição Permanente da Amazônia (EPA, 1967-1972) assembled a rich, still incompletely studied material of fishes from the Amazon river basin. Among material collected in the rio Negro we found specimens of a new species of Polycentrus which differ considerably from material collected along the Atlantic coast and it is diagnosed and described herein.

${ }^{1}$ Universidade Federal do Piauí, Campus Prof ${ }^{a}$. Cinobelina Elvas, Coordenação do Curso de Licenciatura Plena em Ciências Biológicas, Rodovia BR-135, km 03, Planalto Horizonte, 64.900-000 Bom Jesus, PI. E-mail: dpcoutinho@ufpi.edu.br

${ }^{2}$ Museu Paraense Emílio Goeldi, Caixa Postal 399, 66040-170, Belém, PA, Brazil. E-mail: wolmar@museu-goeldi.br. Send reprint requests to $\mathrm{WBW}$. 


\section{Materials and Methods}

Morphometric and meristic data follow Kullander (1983) and Kullander \& Britz (2002). Measurements were made point to point using a digital caliper, and recorded to the tenth of a millimeter, with the following modifications: body depth at anal-fin origin- measured vertically from the origin of the anal fin to the most dorsal point of the body; body depth at pelvic-fin origin - measured vertically from the origin of the pelvic fin to the most dorsal point; lengths of the bases of the dorsal and anal fins, divided into spinous base length (distance from the base of the first to the last hard rays) and soft base length (distance between the base of the first and last rays). Standard length (SL) is presented in $\mathrm{mm}$, all other measurements are presented as proportions of standard length, except subunits of head, presented as proportions of head length (HL). Counts of the holotype are indicated by an asterisk (*). The frequency of each count is displayed in parentheses after the count. The pores of the sensory system were identified as in Kullander \& Britz (2002). The analysis of the bone and pores was based on cleared and stained specimens following Taylor \& Van Dyke (1985) and radiographs obtained at NRM web-site http://artedi.nrm.se/nrmfish/imgsearch.php (lectotype of Labrus punctatus) and with the apparatus Orion 100, 25 $\mathrm{kv}, 4 \mathrm{~mA}, 30 \mathrm{~s}$. Osteological nomenclature follows Liem (1970). For the color pattern description, the following characters are proposed: postorbital bands - diagonal upper and median horizontal bands, all originating from the posterior margin of the orbit; suborbital band originating from the inferior margin of the orbit; opercular spot for 3-5 sets of surrounding scales, darkly pigmented, forming two or three spots on the opercle. Institutional abbreviations are: ECFP, Estação Científica Ferreira Pena, Portel; IEPA, Instituto de Pesquisas Científicas e Tecnológicas do Estado do Amapá, Macapá; INPA, Instituto Nacional de Pesquisa da Amanônia, Manaus; MBUCV, Museo de Biologia de la Universidad Central de Venezuela, Caracas; MCP, Museu de Ciência e Tecnologia, Pontifícia Universidade Católica do Rio Grande do Sul, Porto Alegre; MPEG, Museu Paraense Emílio Goeldi, Belém; MUSM, Museo de Historia Natural, Universidad Nacional Mayor de Sam Marcos, Lima; MZUSP, Museu de Zoologia da Universidade de São Paulo, São Paulo; NRM, Swedish Museum of Natural History, Stockholm.

\section{Polycentrus jundia, new species} Figs. 1 and 2A; Table 1

Holotype. MZUSP 54586, 28.3 mm SL, Brazil, Amazonas, município de Iranduba, Paricatuba, rio Negro basin, lake on the right bank of the rio Negro, 11 Nov 1972, Expedição Permanente da Amazônia (EPA).

Paratypes. All from Brazil, Amazonas, município de Santa Isabel do Rio Negro, rio Negro basin, collected by EPA. MZUSP 62191, 1, $20.3 \mathrm{~mm} \mathrm{SL}$, lake channel in São João, near Tapurucuara [= Santa Isabel do Rio Negro], 0²4'0"S $65^{\circ} 2^{\prime} 0^{\prime \prime} \mathrm{W}, 23$ Oct 1972. MPEG 29926, 3 (1 c\&s), 19.2$24.9 \mathrm{~mm}$ SL; and MZUSP 55113, 3 (1 c\&s), 15.7-19.6 mm SL, igarapé in São João near Santa Isabel do Rio Negro, 0²4'0"S 65²'0"W, 27 Oct 1972. MZUSP 59204, 1, 19.4 mm SL, igarapé in São João near Santa Isabel do Rio Negro, $0^{\circ} 24^{\prime} 0^{\prime \prime} S 65^{\circ} 2^{\prime} 0^{\prime \prime} \mathrm{W}, 23$ Oct 1972. MZUSP 62169, 1, $10.5 \mathrm{~mm}$ SL, floodplain igarapé of the rio Negro, $0^{\circ} 24^{\prime} 0^{\prime \prime} \mathrm{S}$ $65^{\circ} 2^{\prime} 0^{\prime \prime} \mathrm{W}, 19$ Oct 1972.

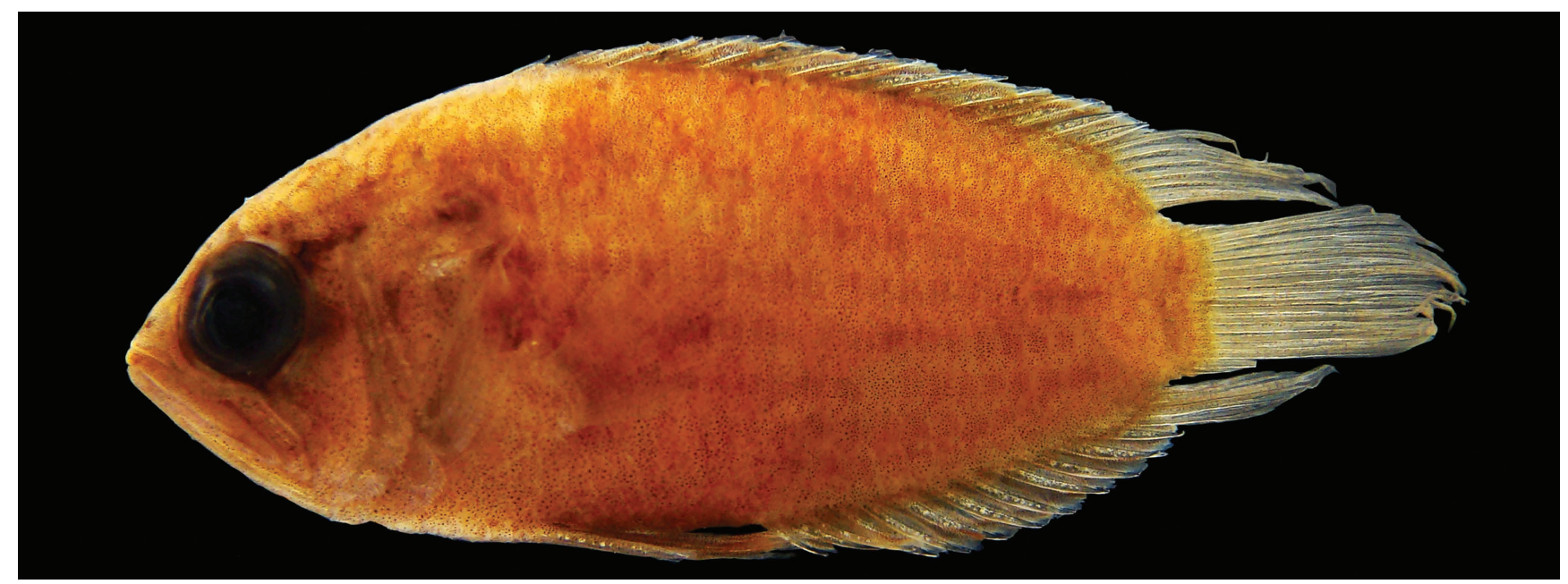

Fig. 1. Polycentrus jundia, new species, holotype, MZUSP 54586, $28.3 \mathrm{~mm}$ SL, Brazil, Amazonas State. Left lateral view.

Diagnosis. Polycentrus jundia is distinguished from $P$. schomburgkii by: diagonal upper postorbital band being shorter than orbital diameter (Fig. 2A) vs. longer (Fig. 2B); presence of the median postorbital horizontal band ( $v s$. absence); subocular band being shorter than orbital diameter (Fig. 2A) (vs. length of subocular band equal to or greater than orbital diameter (Fig. 2B)); snout blunt (vs. protruding); mouth isognathous (vs. prognathous); serrations absent on 
lower edge of lacrimal or two tiny serrations at the posterior end (vs. 8-14 conspicuous serrations distributed throughout the lower edge); posterior edge of vertical arm of preopercle fully serrated (vs. smooth edge); presence of five pungent opercular spines, the three dorsalmost largest (vs. one or two short spines); subopercle widely serrated along most of the edge ( $v s$. no serrations); cleithrum with serrations on posterior dorsal margin ( $v s$. no serrations); interopercle with widely serrated edge ( $v s$. clusters of three to five serrations along the edge of varying position between individuals); fourth pectoral-fin ray reaching vertical through anal-fin origin ( $v s$. reaching vertical from spine III or IV of anal fin); lower number of scales on dorsal-fin base 19-20 (vs. 26-31); lower number of scales on anal-fin base 12-14 (vs. 16-20); the lower number of predorsal scales 19-21 (vs. 28-30); absence of the median opercular blotch ( $v s$. presence).

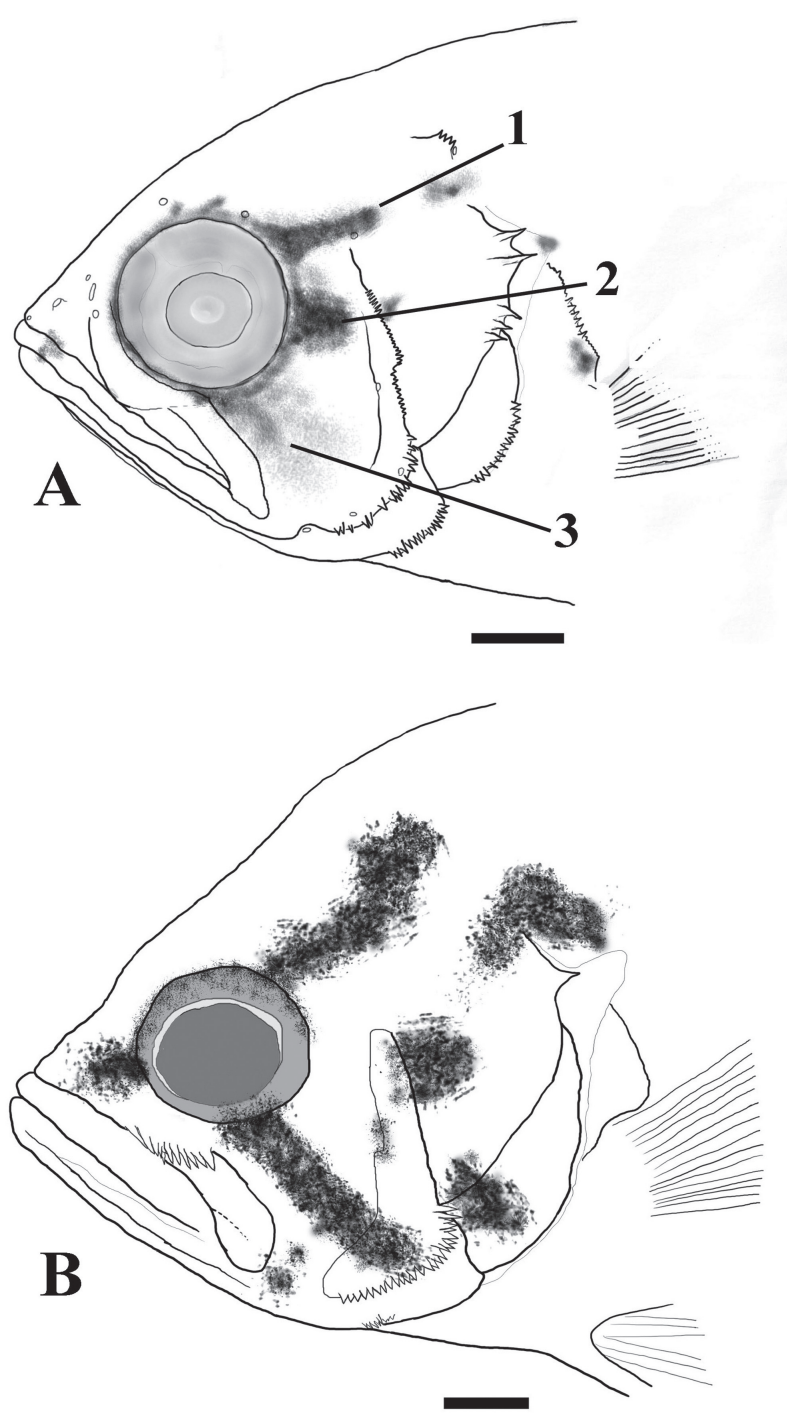

Fig. 2. Left lateral view of the head of (A) Polycentrus jundia, holotype, MZUSP 54586, $28.3 \mathrm{~mm} \mathrm{SL}$, and (B) Polycentrus schomburgkii MPEG 3294, 1, $40.7 \mathrm{~mm}$ SL; (1) upper postorbital diagonal band; (2) postorbital median horizontal band; (3) suborbital diagonal band. Scale bars $=2 \mathrm{~mm}$.
Description. Meristic and morphometric data are shown in Table 1. Body ellipsoid in lateral view, slightly elongate; noticeably compressed and ellipsoid in cross section at median of body length. Dorsal profile convex in long curve with upward slope in predorsal region, continuing in downward convex arc along dorsal-fin base to posteriormost ray. Ventral profile almost straight from lower lip to isthmus, posteriorly arched, slightly convex, from that point to analfin origin, becoming slightly more pronounced from analfin base to last ray. Caudal peduncle compressed, short, deep; straight in both dorsal and ventral profiles.

Table 1. Morphometric data of Polycentrus jundia. SD = Standard deviation. $\mathrm{N}=$ Number of specimens.

\begin{tabular}{|c|c|c|c|c|c|c|}
\hline \multirow[b]{2}{*}{ Standard Length (mm) } & \multirow{2}{*}{$\begin{array}{c}\text { Holotype } \\
28.3\end{array}$} & \multicolumn{2}{|c|}{ Range } & \multirow{2}{*}{$\frac{\text { Mean }}{19.3}$} & \multirow{2}{*}{$\frac{S D}{4.7}$} & \multirow{2}{*}{$\frac{N}{10}$} \\
\hline & & 10.5 & 28.3 & & & \\
\hline & \multicolumn{4}{|c|}{ Percents of Standard Length } & & \\
\hline Preanal distance & 62.2 & 56.2 & 68.1 & 62.0 & 3.2 & 10 \\
\hline Prepelvic distance & 40.9 & 40.0 & 46.3 & 42.4 & 2.0 & 10 \\
\hline Prepectoral distance & 41.7 & 39.2 & 45.2 & 41.3 & 2.1 & 10 \\
\hline Predorsal distance & 43.5 & 41.6 & 50.3 & 44.0 & 3.3 & 10 \\
\hline $\begin{array}{l}\text { Length of spinous dorsal- } \\
\text { fin base }\end{array}$ & 55.1 & 47.5 & 57.0 & 51.5 & 3.0 & 10 \\
\hline $\begin{array}{l}\text { Length of dorsal fin base } \\
\text { with branched rays }\end{array}$ & 7.4 & 7.0 & 9.2 & 8.1 & 0.8 & 10 \\
\hline $\begin{array}{l}\text { Length of spinous anal- } \\
\text { fin base }\end{array}$ & 31.8 & 29.4 & 36.4 & 32.8 & 2.4 & 10 \\
\hline $\begin{array}{l}\text { Length of anal-fin base } \\
\text { with branched rays }\end{array}$ & 6.7 & 5.6 & 8.3 & 6.6 & 0.9 & 10 \\
\hline Pectoral-fin length & 20.1 & 9.3 & 20.1 & 15.7 & 3.4 & 10 \\
\hline Pelvic-fin length & 24.7 & 21.0 & 35.4 & 29.3 & 4.3 & 10 \\
\hline Caudal-peduncle depth & 13.8 & 13.2 & 16.8 & 15.0 & 1.1 & 10 \\
\hline Body depth at anal origin & 42.4 & 38.0 & 42.4 & 40.4 & 1.3 & 10 \\
\hline Body depth at pelvic origin & 41.7 & 39.1 & 44.4 & 41.4 & 1.8 & 10 \\
\hline \multirow[t]{2}{*}{ Head length } & 38.9 & 37.1 & 44.2 & 39.2 & 2.6 & 10 \\
\hline & \multicolumn{4}{|c|}{ Percents of Head Length } & & \\
\hline Snout length & 22.7 & 15.9 & 22.7 & 19.5 & 2.2 & 10 \\
\hline Horizontal orbit diameter & 30.9 & 29.2 & 40.9 & 34.5 & 3.8 & 10 \\
\hline Head width & 55.4 & 50.5 & 63.8 & 56.0 & 4.5 & 10 \\
\hline Least interorbital distance & 25.4 & 21.3 & 28.1 & 24.1 & 2.2 & 10 \\
\hline Head depth & 95.4 & 76.6 & 100.9 & 89.9 & 7.4 & 10 \\
\hline
\end{tabular}

Head in dorsal view, broad and rounded; obtuse in lateral profile. Males in reproductive state with discrete adipose gibbosity in occipital region. Snout broad, short, obtuse. Mouth wide, protractile, terminal, isognathous, and directed obliquely dorsally; anterior extremity at half of head depth, bordered by thin lips. 
Dentigerous plate with villiform teeth on premaxilla from anterior margin up to one quarter of ascending process; villiform teeth on dentary from inner edge of mandibular symphysis to angulo articular. Ascending process of premaxilla half length of neurocranium. Absence of dentigerous plates on parasphenoid, ectopterygoid, basihyal and third hypobranchial.

Posterior tip of maxillary reaching vertical through posterior border of orbit or slightly anteriorly. Ventral margin of lacrimal smooth, single specimen with two tiny serrations posteriorly. Horizontal process of preopercle serrated, edge of ascending process with tiny serrations, straight up to pore $\mathrm{p} 5$, convex between $\mathrm{p} 5$ and p6-7.

Two conspicuous spiny processes on posterodorsal edge of opercle, dorsal to two or three serrations. Interopercle with smooth ventral edge on anterior third, serrated posteriorly. Subopercle with serrations at median region of length, anterior and posterior regions smooth. Three or four tiny serrations on posttemporal. Cleithrum serrated (10 or 11 tiny serrations) on posterior dorsal margin.

Sensory canal system with tiny pores: angulo-articular aal and 2, dentary d2-4, extrascapular ex 3 and 4, frontal f2 and 3, lacrimal 11-3, nasal $\mathrm{n} 1$ and 2, preopercle p1-5, posttemporal po2, and pterotic pt2 and 3. Coronal and infraorbital pores absent. Series of neuromasts bordering infraorbital region. Lateral line restricted to single scale posterior/ventral to posttemporal.

Scale series: predorsal, 19(1), 20(7) and 21*(1); vertical, $12(3), 14 *(3)$ or $15(1)$; horizontal, $20(1), 21(2), 23 *(3)$ or 24(1); circumpeduncular, 15(1) or $16^{*}(4)$. Cycloid scales in predorsal and ventral regions and anterior margin of preopercle. Ctenoid scales on cheek, subopercular, interopercular and opercular regions. Ctenoid scales moderately large on posterior region of body.

Scale sheath on dorsal fin present, free from base of fin, evident from spine IV, half to one scale deep on terminal portion of fin base, ending ventral to base of soft rays. Scale sheath on anal fin present, free from fin base, one scale deep, evident throughout extension.

Dorsal-fin rays XVI.8*(8), XVI.7(1) or XV.9(1), origin at posterior margin of opercular process and on insertion of dorsal opercular bone, spine I shortest, equivalent to one third of spine IV, which longest. First and last soft rays unbranched; remaining soft rays branching once on distal quarter.

Pectoral-fin rays ii,11(1), 12(8) or 14*(1), fourth branched longest; fin reaching vertical through anal-fin origin, edge rounded, rays branching once on distal quarter. Pelvicfin rays I,5, spine nearly straight, distal tip of fin reaching urogenital opening, second ray longest, reaching beyond urogenital opening, proportionately shorter in females, reaching beyond anal-fin spine IV in male specimens.

Anal-fin rays XII.6*(6), XI.6(2) or XII.5(2) rays, origin at vertical through insertion of dorsal-fin seven; distal tip of soft rays reaching half length of caudal fin. Insertion of soft rays of dorsal and anal fins at $45^{\circ}$. Distal tip of soft portions of dorsal and anal fins slightly tapered. Caudal fin subtruncate or slightly convex when expanded, dorsal and ventral rays slightly shorter than central rays; caudal-fin rays $I, 7+7, i$; not covered with scales.

Vertebrae, 11(2) preanal + 12(2) caudal. Pleural ribs 7(2). Branchiostegal rays 6(2).

Dentary teeth 82-100 in one side, all sharp, short, those near symphyseal region larger, gradually decreasing posteriorly; teeth of symphysis in four irregular series on large part of tooth-plate, teeth close to coronoid process in two or one series. Premaxillary teeth about 150 in one side, in five irregular series, all sharp, short; medialmost teeth larger, gradually decreasing posteriorly.

Pharyngeal lower tooth-plate, paired, dorsoventrally compressed with long posterior process and moderate anterior process; around 60 short teeth similar in size, slightly curved latero-posteriorly, posterior medial slightly larger, irregularly distributed, not in rows (Fig 3).

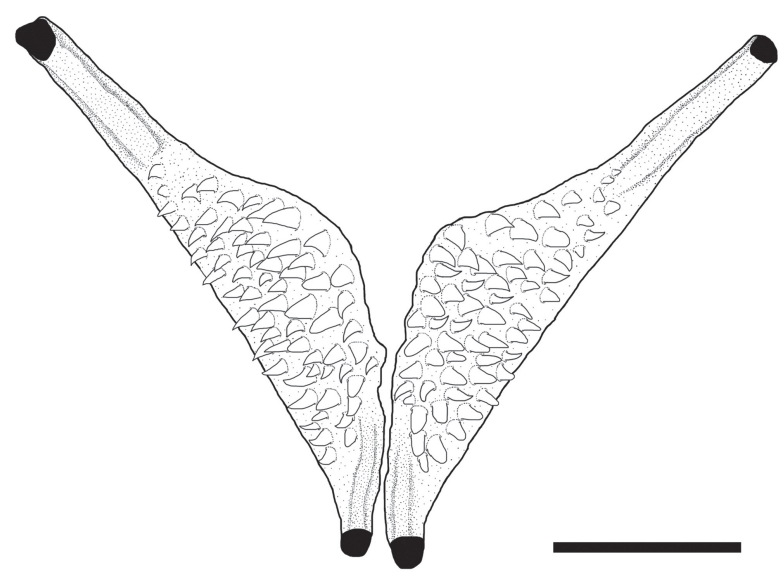

Fig. 3. Lower pharyngeal tooth-plate of Polycentrus jundia, in occlusal view, MZUSP 55113, paratype. Scale bar $=1$ $\mathrm{mm}$.

Sexual dimorphism. Presence of discrete adipose gibbosity between the occipital and coronal region in males, absent in females. Vent of gravid females yellowish in individuals preserved in alcohol.

Color in alcohol. Ground color light brown with dark brown, diffuse chromatophores forming longitudinal series of dark spots, surrounded by pale spots. Scales usually lighter at focus, with darker submarginal pigmentation. Upper postorbital diagonal band black or dark brown, located postero-dorsally, ascending from orbital margin parallel to predorsal profile towards posttemporal, formed by contiguous points variably coalescing, forming a short band. Postorbital median horizontal band black or dark brown, postero-medial, horizontal, originating at orbital margin, formed by two adjacent blotches, gradually becoming lighter onto preopercle, continuing posteriorly as two points forming rounded spot on proximal medial region of opercle. Suborbital diagonal band, inconspicuous, 
postero-ventral, inclined ventrally towards prepelvic region, formed by scattered chromatophores onto five to seven scales. Preorbital band inconspicuous, brown, located antero-dorsally, extending from lacrimal towards dentary. A single blotch, not sharply defined, dorsally to dorsal extremity of opercle; a little blotch, few sharp, close to posterior extremity of opercle; a little blotch, few sharp, at posterior border of cleithrum, close to pectoral-fin base.

Region between preopercle and posterior margin of orbit paler than background. Humeral blotch brown, circular or irregular. Juveniles (below $20.0 \mathrm{~mm} \mathrm{SL}$ ) with four vertical, inconspicuous bars originating beneath spines I-III, V-VII, IX-XI, XIII-XV; bars absent in adults (larger than $20.1 \mathrm{~mm}$ $\mathrm{SL})$.

Base of dorsal-fin spines dark brown, distal margin whitish or hyaline, five or six notorious brown spots onto rays IV and XII, intervening membrane of branched rays hyaline, rays outlined by row of dark chromatophores.

Intervening membranes of anal-fin spiny portion dark brown, distal margin with a narrow whitish or hyaline border, intervening membranes of branched rays hyaline, with distinct dark spot at base of rays 1-4, rays 1-7 outlined by single row of dark chromatophores.

Pelvic fin dark brown, distal margin with narrow, whitish or hyaline border, pale rays opaque distally. Intervening membranes of pectoral-fin rays hyaline; rays ii/12-14 outlined by single row of black chromatophores. Caudal fin mostly hyaline with tiny brown chromatophores outlining all rays, black chromatophores, and sparse scattered pigmentation onto intervening membranes.

Etymology. The epithet "jundia" comes from the Tupi word "jundiá" meaning "head with spine", and refers to the large amount of serrations present on the head bones of the new species. Treated here as a noun in apposition.

Distribution. Polycentrus jundia is known from floodplain igarapés of the lower and upper rio Negro (Fig. 4).

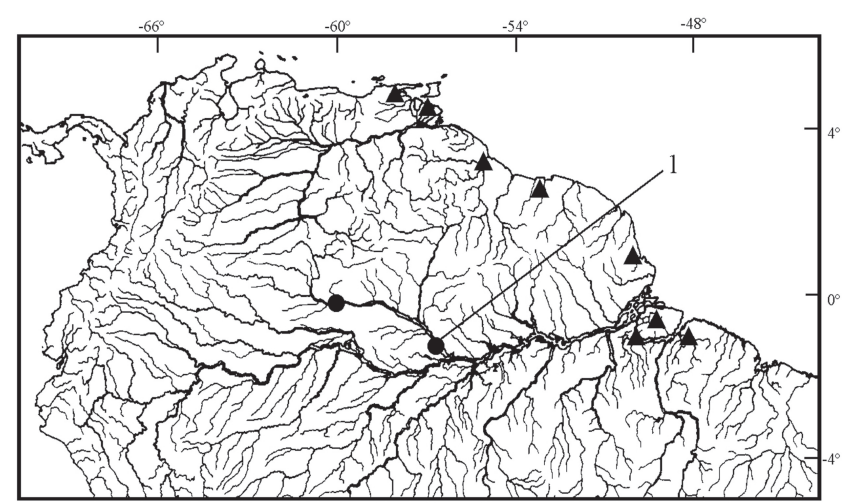

Fig. 4. Map of north of South America. Black circles are collection sites of Polycentrus jundia, new species; $1=$ type locality. Black triangles are distribution of Polycentrus schomburgkii. Some points may represent more than one locality.

\section{Discussion}

The allocation of Polycentrus jundia in the present genus is justified by the color pattern shared with $P$. schomburgkii formed by longitudinal series of dark spots, surrounded by pale spots (vs. marbled pattern without horizontal series of points in Monocirrhus); the number of spines on anal fin, 11-13 (vs. four in Afronandus, or 9-12 in Polycentropsis - Nelson, 2006); a single perforated scale on upper lateral line (vs. five or six in Polycentropsis or perforated scales absent in Afronandus - Berra, 2001); preopercle serrations small and directed ventrally ( $v s$. conspicuously developed and directed antero-ventrally in Afronandus - Liem, 1970: fig. 18); the number of analfin pterygiophores (16 or $17 \mathrm{vs}$. nine in Afronandus, and 23 or 24 in Monocirrhus); the absence of mandibular barbel ( $v s$. barbel present in Monocirrhus), the absence of scales on caudal fin base (vs. $3 / 4$ of caudal fin with scales in Monocirrhus); the serrations present on border of ventral interopercle (vs. absent in Monocirrhus); and the lack of posterior lateral line ( $v s$. occasionally present in Monocirrhus).

The distribution pattern of Polycentrus jundia on the lower and upper Rio Negro is disjunct from its congener (P. schomburgkii), occurring in the mouth of the Río Orinoco, on Trinidad and Tobago, in coastal rivers of the Guiana shield, and in coastal rivers in near the mouth of the Amazon (Brazil), including the Ilha de Marajó. A similar pattern of distribution was observed by Vari (1988) among Curimatidae (Characiformes) groups, and proposed nine areas of endemism for South America. Thus, the distribution of Polycentrus jundia is contained within the center of endemism "Amazon" (sensu Vari, 1988), whereas the distribution of $P$. schomburgkii is contained within the area of endemism "Guianas" (sensu Vari, 1988), reaching the mouth of the río Orinoco, in the area of endemism "Orinoco", north, to the opposite extremity, south, occurs at the mouth of the rio Amazonas that shares the mouth of the rio Tocantins. Some genera share disjunct distribution of species involving both the rio Negro and Amazon basins. The genus Osteoglossum Cuvier (Osteoglossiformes) is composed of $O$. ferreirai Kanazawa, restricted to the rio Negro (Kanazawa, 1966; Ferraris, 2003), and its congener, O. bicirrhosum (Cuvier), which occurs in the rio Amazonas, rio Oiapoque and coastal rivers of the Guianas. The cichlid genus Apistogramma Regan, with more than 60 valid species (Kullander \& Ferreira , 2005), has seven species (about 10\%) restricted to the rio Negro (Kullander, 2003). There are other patterns of distribution, such as that of Corydoras La Cepède (Callichthyidae), with over 12 species restricted to the rio Negro (Britto \& Lima, 2003). Considering the high number of fish species restricted to the rio Negro, it is clear that this drainage is a large area that requires further efforts on taxonomic and biogeographic studies in order to understand the processes that may have caused his high endemic biodiversity. 
The two most distinctive characteristics observed in Polycentrus jundia are the presence of serrations on the posterior edge of the subopercle and, also, on the posterior edge of the dorsal process of the cleithrum (Fig. 2). The subopercle of Polycentrus jundia is drop-shaped with a digitiform process anteriorly facing the edge of the lower portion, very similar to that illustrated in Liem (1970; fig. 19). However, part of the ventral and posterior border of the bone is notoriously covered with serrations in both juvenile and adult individuals. Considering that Polycentrus schomburgkii, as well as the other species of the Polycentridae (Monocirrhus polyacanthus Heckel, Afronandus sheljuzhkoi Meinken and Polycentropsis abbreviata Boulenger) lack a serrated subopercle, the presence of this characteristic in Polycentrus jundia can be hypothesized as an autapomorphy. It is worth mentioning that the serrated edge of the ctenoid scales may possibly, be confused with the smooth edge of the subopercle that occurs in Polycentrus schomburgkii.

The general aspect of the cleithrum of Polycentrus jundia is sigmoidal with the dorsal part expanded posteriorly, as described and illustrated by Liem (1970: fig. 26 for Polycentropsis abbreviata and fig. 38 for M. polyacanthus). However, in Polycentrus jundia it is slightly less sinuous and the dorsal part is slightly wider, with its posterior border featuring serrations along most of its length, present in all small and large specimens. All specimens of Polycentrus schomburgkii, $M$. polyacanthus and Polycentropsis abbreviata analyzed had a smooth posterior dorsal edge of the cleithrum, confirming the condition illustrated by Liem (1970). Specimens of $A$. sheljuzhkoi were not examined in this study and Liem (1970) did not illustrate the cleithrum of that species. However, it is possible that the presence of serrations on the cleithrum of Polycentrus jundia is an autapomorphy.

On the preopercle of the analyzed specimens of Polycentrus schomburgkii, the ventral margin of the horizontal arm predominates with discontinuous serrations, separated by spaces occupied by the pores of the sensory canal of the preoperculo-mandibular laterosensory branch, located more frequently on the ventral margin and, occasionally, anterior to the margin, not interrupting the marginal serrations. The posterior edge of the vertical arm of the preopercle in Polycentrus schomburgkii is smooth and serrations are absent in all specimens analyzed, similar to that described and illustrated by Liem (1970, fig. 19). Polycentrus jundia shares with P. schomburgkii the serrations on the ventral edge of the horizontal arm, although it is notoriously distinguished from this species by presenting minute serrations along the entire posterior edge of the vertical arm. The presence of such serrations on the posterior border of the preopercle is shared with Afronandus sheljuzhkoi (Liem, 1970, fig. 18) among the Polycentridae.

A striking feature of Polycentrus schomburgkii shared with Polycentropsis abbreviata is the presence of serrations on the lacrimal, as already mentioned in the original description of Müller \& Troschel (1849a). Invariably, all small to large specimens have 8-15 serrations on the lower edge of the lacrimal, directed ventrally, occasionally interrupted by pores of the infraorbital branch of the sensory canal. In Polycentrus jundia these are most frequently absent, although two tiny serrations close to the posterior end of the lacrimal were observed in a single specimen.

The interopercle of Polycentrus schomburgkii, illustrated by Liem (1970, fig. 19), shows the ventral edge with discontinuous serrations. Although slightly different, serrations on the interopercle of the specimens analyzed of that species were observed to be variably distributed, being restricted to the anterior portion of the horizontal ventral edge, discontinuous, or completely absent. In Polycentrus jundia, the serrations extend along the entire horizontal ventral edge.

The postorbital median horizontal band of Polycentrus jundia, also present in Monocirrhus, is not shared with Polycentrus schomburgkii, nor with the individuals of Polycentropsis analyzed.

As noted above, the shared characters identified and analyzed in this work are satisfactorily congruent to allocate Polycentrus jundia in this genus. However, the characters are incongruent for understanding the relationships between the genera of Polycentridae. Relations within Polycentridae were analyzed by Britz (1997), which estimated that the neotropical polycentrids (Polycentrus and Monocirrhus) comprise a monophyletic group, sister of Polycentropsis (West African) based on the analyzes of the egg surface structure and larval cement glands, not involving morphological analysis. Therefore, to understand the relationships of the genera of Polycentridae is required a more comprehensive and detailed analysis, beyond the scope of this proposal.

Comparative Material. Monocirrhus polyacanthus. Brazil. Amapá. MCP 42808, 1, 49.2 mm SL, Mazagão, córrego Itaubal. MPEG 9057, 8, 48.3-56.4 mm SL, Chaves, igarapé Miri. Amazonas. MPEG 4053, 1, 71.8 mm SL, São Gabriel da Cachoeira, rio Tiquié, cachoeira, $1 \mathrm{~km}$ from the aldeia São João. MPEG 16053, 1, 49.8 mm SL, Maués, rio Paraconi, rio Madeira. MZUSP 7377, 2, 23.7 and $29.2 \mathrm{~mm}$ SL, Maués, igarapé Limãozinho, rio Madeira. Pará. MPEG 8310, 1, 58.9 mm SL, Bragança, rio Chumucuí. MPEG 11922, 4, 56.7-76.3 mm SL, Benevides, igarapé Taiassuí. MPEG 11924, 7, 45.3-77.2 mm SL, Benevides, igarapé Itá. MZUSP 8427, 3, 35.9-54.6 mm SL, Alter do Chão, igarapé Jacundá, rio Tapajós. MZUSP 63742, 6, 28.1-40.5 mm SL, igarapé Candiru-Mirim. MZUSP 63749, 9, 29.0-43.1 mm SL, Aveiro, igarapé Açú, rio Tapajós. Rondônia. MCP 39105, 1, 67.3 mm SL, Guajará-mirim, igarapé Bananaeiras, rio Madeira. Peru. Loreto. MCP 37383, 1, 60.0 mm SL, Jenaro Herrera, Quebrada Salomé. MUSM 4475, 5, 40.0-43.72 mm SL, Maynas, Iquitos río Ucayali. Polycentropsis abbreviate. Beni. Plateau, Lagbe, rio Iguid. MZUSP 84549, 1, $62.3 \mathrm{~mm}$ SL, bridge over the river Iguid, road RNIE1. MZUSP $84794,6,12.3-41.8 \mathrm{~mm} \mathrm{SL}$, rio Iguid, near the old train station Gbokoutou. MZUSP 84577, 6, 24.8-34.0 mm SL, Zou, swamp in 
the village Locoli. Polycentrus schomburgkii. Brazil. Amapá. IEPA 1893, 29, 13.3-29.4 mm, lago Pracuúba. IEPA 2666, 54, 25.5-34.3 mm SL, Tartarugalzinho, rio Flechal. MPEG 3294, 1, 40.7 mm SL, rio Amapá, município de Amapá, flooded savannas. Pará. MPEG 7578, 1, $33.0 \mathrm{~mm}$, Ponta de Pedras, igarapé São Domingos, rio Quiã-Paranã. MPEG 9912, 1, 29.1 mm, Barcarena, Vila dos cabanos, igarapé Caripi-açu. MPEG 10403, 7, 28.9$32.6 \mathrm{~mm} \mathrm{SL}, 1 \mathrm{C} \& \mathrm{~S}, 32.6 \mathrm{~mm}$ SL, Melgaço, igarapé Santa Rosa. MPEG 11258, 1, 16.5 mm, Melgaço, lago Cacuri-Estação Científica Ferreira Penna. MPEG 29925, 33, 5 c\&s, 14.8-32.2 $\mathrm{mm}$, Barcarena, ilha Trambioca, stream at road to the beach at Cirituba. Suriname. Para. MZUSP 65447, 3, 22.5-40.4 mm SL, Coropina creek, tributary of the rio Suriname, bathing resort Republiek. Paramaribo. MZUSP 65421, 1, 34.2 mm SL, channel, Leonsberg. MZUSP 76390, 2, 34.8 and $42.0 \mathrm{~mm}$ SL, road Henri Fernandes, near the sea. Venezuela. Monagas. MBUCV-V 13275, 4, 17.6-31.1mm SL, laguna El Guatero, Barrancas. Sucre. MBUCV-V 12271, 2, 26.2 and $34.2 \mathrm{~mm} \mathrm{SL}$, Acequia de Leandro, $\mathrm{S}$ of Guaraunos. MBUCV-V 22454, 4, 18.9-37.2 mm SL, Caribe Basin, Turuepano, Ajies, small channel from canal Ajies, about $3 \mathrm{~km} \mathrm{~S}$ of Village Ajies. MBUCV-V 35626, 4, 16.9-42.8 mm SL, rio Orinoco drainage, Guiria, Quebrada tributary of La Laguna Salineta.

\section{Acknowledgments}

We thank CAPES for the scholarship and funding through the National Program of Academic Cooperation - PROCAD-NF. 23038.042984/2008-30. We are grateful to André Netto-Ferreira for comments and suggestions on the manuscript. We also thank the following curators and technicians of the collections for allowing access and loaning material: Margarete Lucena e Carlos Lucena (MCP), Lúcia Py-Daniel (INPA), José Lima e Osvaldo Oyakawa (MZUSP), Cecile Gama (IEPA), Hernán Ortega and Jessica Espino (MUSM-Lima), Homero Sanchez (IAAPIquitos), Francisco Provenzano (MBUCV). We thank Sven Kullander (NRM) for providing images of the lectotype of P. schomburgkii. WBW thanks the Conselho Nacional de Desenvolvimento Científico e Tecnológico (CNPq) for the continuous support (process \# 304754/2011-0).

\section{Literature Cited}

Berra, T. M. 2001. Freshwater fish distribution. San Diego, Academic Press.

Britto, M. R. \& F. C. T. Lima. 2003. Corydoras tukano, a new species of corydoradine catfish from the rio Tiquié, upper rio Negro basin, Brazil (Ostariophysi: Siluriformes: Callichthyidae). Neotropical Ichthyology, 1: 83-91.

Britz, R. 1997. Egg surface structure and larval cement glands in nandid and badid fishes with remarks on phylogeny and biogeography. American Museum Novitates, 3195: 1-17.

Britz, R. \& S. O. Kullander. 2003. Family Polycentridae (Leaffishes). Pp. 603-604. In: Reis, R. E., S. O. Kullander \& C. J. Ferraris, Jr. (Eds.). Check List of the Freshwater Fishes of South and Central America. Porto Alegre, Edipucrs.
Ferraris, C. J., Jr. 2003. Family Osteoglossidae. Pp. 30. In: Reis, R. E., S. O. Kullander, \& C. J. Ferraris, Jr. (Eds.). Check List of the Freshwater Fishes of South and Central America. Porto Alegre, Edipucrs.

International Commission of Zoological Nomenclature. 2000. Opinion 1954. Labrus Linnaeus, 1758, Cichlasoma Swainson, 1839 and Polycentrus Müller \& Troschel, 1849 (Osteichthyes, Perciformes): conserved by the designation of Labrus mixtus Linnaeus, 1758 as the type species of Labrus and L. bimaculatus Linnaeus, 1758 as the type species of Cichlasoma; and Polycentrus schomburgkii Müller \& Troschel, 1849: specific name given precedence over L. punctatus Linnaeus, 1758. Bulletin of Zoological Nomenclature, 57: 131-136.

Kanazawa, R. H. 1966. The fishes of the genus Osteoglossum with a description of a new species from the Rio Negro. Ichthyologica, the Aquarium Journal, 37: 161-172.

Kullander, S. O. 1983. A revision of the South American cichlid genus Cichlasoma (Teleostei: Cichlidae). Stockholm, Naturhistoriska Riksmuseet.

Kullander, S. O. 2003. Family Cichlidae (Cichlids). Pp. 605-654. In: Reis, R. E., S. O. Kullander, \& C. J. Ferraris, Jr. (Eds.). Check List of the Freshwater Fishes of South and Central America. Porto Alegre, Edipucrs.

Kullander, S. O. \& R. Britz. 2002. A revision of the family Badidae (Teleostei: Perciformes), with description of a new genus and ten new species. Ichthyological Exploration of Freshwaters, 13: 295-372.

Kullander, S. O. \& E. J. G. Ferreira 2005. Two new species of Apistogramma Regan (Teleostei: Cichlidae) from the rio Trombetas, Pará State, Brazil. Neotropical Ichthyology, 3: 361-371.

Liem, K. F. 1970. Comparative functional anatomy of the Nandidae (Pisces: Teleostei). Fieldiana. Zoology, 56: 1-166.

Müller, J. \& F. H. Troschel. 1849a. Fische. Pp. 618-644, In: Schomburgk, R. Reisen in Britisch-Guiana in den Jahren 1840-44. Im Auftrag Sr. Mäjestat des Königs von Preussen. Versuch einer Fauna und Flora von Britisch-Guiana. Leipzig, Verlagsbuchhanlung von J.J. Weber.

Müller, J. \& F. H. Troschel. 1849b. Horae Ichthyologicae. Beschreibung und Abbildung neuer Fische. Erstes und zweites Heft. Mit elf Kupfertafeln. Die Familie der Characinen. Berlin, Verlag von Veit \& Comp.

Nelson, J. S. 2006. Fishes of the world. New York, John Wiley $\&$ Sons.

Paepke, H. J. 1993. Polycentrus schomburgkii Müller \& Troschel, 1848 (Osteichthyes, Perciformes): proposed conservation of the specific name. Bulletin of Zoological Nomenclature, 50: 215-218.

Taylor, W. R. \& G. C. van Dyke. 1985. Revised procedures for staining and clearing small fishes and other vertebrates for bone and cartilage study. Cybium, 9: 107-119.

Vari, R. P. 1988. The Curimatidae, a lowland Neotropical fish family (Pisces, Characiformes); distribution, endemism, and phylogenetic biogeography. Pp. 343-377. In: Vanzolini, P. E. \& W. R. Heyer (Eds.). Proceedings of a Workshop on Neotropical Distribution Patterns. Rio de Janeiro, Academia Brasileira de Ciências.

Submitted August 23, 2013 Accepted September 17, 2014 by Paulo Lucinda Published December 27, 2014 
